\title{
Kajian ethylene triple response terhadap kecambah tiga varietas kedelai (Study of ethylene triple response on the seedlings of three varieties of soybean)
}

\author{
Kartika Eka Wardani ${ }^{2)}$, Feky R. Mantiri ${ }^{\left.i^{*}\right)}$, Nio Song $A i^{1)}$, Marhaenus Rumondor ${ }^{1)}$ \\ 1) Jurusan Biologi FMIPA Universitas Sam Ratulangi \\ ${ }^{2)}$ Alumni Jurusan Biologi FMIPA Universitas Sam Ratulangi \\ ${ }^{*}$ Email korespondensi: fmantiri@yahoo.com
}

Diterima 18 Agustus 2014, diterima untuk dipublikasikan 30 Agustus 2014

\begin{abstract}
Abstrak
Keterbatasan lahan tanam di Indonesia merupakan salah satu faktor pembatas dalam pembudidayaan tanaman kedelai. Oleh sebab itu kedelai di tumpangsarikan dengan tanaman lain, sehingga ternaungi. Naungan pada tanaman menyebabkan tingginya produksi etilen sehingga tanaman akan memunculkan triple response yang dapat mempengaruhi pertumbuhan dan perkembangan tanaman. Oleh sebab itu, penelitian ini dilakukan untuk menyeleksi varietas kedelai yang tahan dengan adanya peningkatan etilen pada tiga varietas kedelai (Edamamik, Anjasmoro, Wilis). Setelah dikecambahkan selama 5 hari, panjang kedelai varietas Wilis yang diberi etilen (karbid) adalah yang tertinggi dan Anjasmoro adalah yang terendah. Bengkokan kedelai dengan derajat terendah diamati pada varietas Wilis dibandingkan dengan dua varietas lain. Diameter ketiga varietas tidak berbeda antara yang normal dan diperlakukan dengan karbid. Pengamatan ketiga parameter ini menunjukkan varietas Wilis adalah tanaman yang tahan terhadap peningkatan etilen, sehingga varietas ini berpotensi untuk ditanam di naungan.

Kata kunci: etilen, triple response, kedelai
\end{abstract}

\begin{abstract}
Limitation of arable land in Indonesia is one of the limiting factors in soybean cultivation. Consequently, soybean is sometimes cultivated as an intercropping crop. One of the major problems of intercropped plants is shading. Shading triggers increased production of ethylene, which in turn affects germinating seeds to exhibit ethylene triple response. The study aimed to screen different varieties of soybean (i.e., Edamamik, Anjasmoro, Wilis) for resistance to increased consentrationof ethylene. Results showed that five days after germination, the height of Wilis was the highest, while the height of Anjasmoro was the lowest. Similarly, the degree of hook on Wilis was the lowest compared with the other varieties. Meanwhile, the diameter of the seedlings was not significantly different among the three varieties. Based on these findings it was concluded that Wilis variety was the most resistant to increased concentration of ethylene and therefore was most suited for intercropping (shade environment).
\end{abstract}

Keywords: ethylene, triple response, soybean 


\section{PENDAHULUAN}

Tanaman kedelai (Glycine max (L.) Merr) merupakan tanaman semusim yang telah lama dikenal dan dibudidayakan. Kedelai adalah sumber protein nabati utama bagi masyarakat yang digunakan dalam berbagai macam produk makanan dan merupakan salah satu komoditas pangan utama setelah padi dan jagung yang penting dalam industri pangan serta pembangunan pertanian (Badan Tenaga Nuklir Nasional 2009).

Lingkungan tumbuh seperti tanah, iklim, kelembaban, serta curah hujan yang baik sangat mempengaruhi pertumbuhan dan perkembangan kedelai. Tanaman kedelai umumnya tumbuh optimum pada suhu $20-25^{\circ} \mathrm{C}$, sedangkan suhu tanah yang optimum untuk proses perkecambahan adalah $30^{\circ} \mathrm{C}$. Proses perkecambahan akan menjadi sangat lambat pada suhu yang rendah $\left(<15^{\circ} \mathrm{C}\right)$. Hal ini dikarenakan perkecambahan biji tertekan pada kondisi kelembaban tanah tinggi. Tanaman kedelai dapat tumbuh baik di tempat yang terbuka sehingga menerima cahaya matahari penuh dengan curah hujan 100-400 $\mathrm{mm} 3 /$ bulan serta ditanam di daerah yang terletak kurang dari $400 \mathrm{~m}$ diatas permukaan laut (Hidayat 1993).

Karena keterbatasan lahan tanam maka pembudidayaan tanaman kedelai di Indonesia menggunakan sistem tumpangsari, yaitu pola penanaman lebih dari satu jenis tanaman secara bersamaan di lahan tegakan. Tumpang tindihnya kedelai dengan tanaman lain menyebabkan tanaman kedelai ternaungi sehingga kurangnya sinar matahari yang diterima maka perlunya varietas kedelai yang mempunyai adaptasi besar terhadap naungan (Warsana 2009 dalam Permanasari dan Katsono 2012). Naungan pada tanaman kedelai menyebabkan tingginya produksi etilen sehingga dapat mempengaruhi produksi tanaman.
Etilen merupakan hormon tumbuhan (fitohormon) berwujud gas yang biasanya diproduksi oleh tanaman dalam jumlah tertentu, dengan adanya faktor cekaman lingkungan seperti naungan, kekeringan, kebanjiran, tekanan mekanis, pelukaan serta infeksi memicu tanaman untuk memproduksi etilen secara berlebihan sehingga menghambat pertumbuhan tanaman (Ningrum 2013).

Kemudian pada tahun (19011926) Dimitry Neljubow menunjukkan bahwa etilen menyebabkan respon rangkap tiga atau triple response pada kecambah kacang kapri. Triple response yang dimaksud antara lain menghambat pemanjangan batang, menebalkan batang dan munculnya kebiasaan membuat lekukan (hook) yang menyebabkan batang tumbuh secara horizontal atau mendatar (Salisbury dan Ross 1995). Penelitian ini bertujuan untuk mencari varietas kedelai yang kurang sensitif terhadap etilen serta direfleksikan dalam bentuk respons yang minimal terhadap etilen (triple response).

\section{METODE PENELITIAN}

Penelitian ini dilaksanakan pada bulan Juni sampai Juli 2014 selama 2 minggu di Laboratorium Ekologi Jurusan Biologi FMIPA Universitas Sam Ratulangi. Bahan penelitian yang digunakan ialah benih kedelai 3 varietas yaitu Edamamik, Anjasmoro dan Wilis. Penelitian ini dirancang dengan menggunakan Rancangan Acak Lengkap (RAL) faktorial berupa 2 faktor yaitu faktor varietas (3 varietas) dan faktor ada tidaknya karbid.

Tahapan kerja dalam penelitian ini meliputi pemilihan benih, sterilisasi benih dan media, penanaman kedelai dan pembuatan gas etilen. Parameter yang diamati adalah panjang hipokotil yaitu mengukur panjang dengan menggunakan penggaris, kemudian diameter hipokotil diukur dengan 
menggunakan jangka sorong dan derajat bengkokan (hook) kedelai diukur dengan menggunakan busur derajat pada bagian epikotil kedelai. Kemudian melihat bentuk sel epidermis kecambah dengan membuat irisan melintang pada bagian hipokotil.

Untuk sterilisasi benih dan media, benih direndam di dalam air selama 1 jam dengan tujuan untuk mengetahui kualitas benih. Benih yang tenggelam di dasar wadah merupakan benih yang baik digunakan dalam penelitian, sedangkan benih yang terapung adalah benih yang kurang baik dan tidak digunakan. Benih kedelai disterilisasi dengan menggunakan $\mathrm{NaOCl}$ (pemutih komersial) $2 \%$ selama 5 menit kemudian dibilas dengan akuades sebanyak 3 kali (Nio et al., 2010). Selanjutnya sterilisasi media, yaitu digunakan 90 lembar kertas merang berukuran $30 \times 20 \mathrm{~cm}$ dengan memakai oven selama 24 jam pada suhu $70^{\circ} \mathrm{C}$ (BPTH Bali Nusra, 2009). Kemudian penanaman kedelai, dilakukan dengan metode uji kertas digulung dan di dirikan dalam plastik (UKDdp) (Kartasapoerta, 1992). Dua lembar kertas merang yang sudah dibasahi dihamparkan diatas alas plastik lalu ditanam 25 benih kedelai pada 15 gulungan kertas merang untuk setiap varietas.

Setelah itu, diambil 1 lembar kertas merang yang sudah basah untuk menutupi dan selanjutnya digulung dan di dirikan. Kemudian diletakkan dalam 2 buah kardus dimana masing-masing kardus di isi dengan 15 gulungan kedelai. Pada kardus pertama kedelai ditumbuhkan secara normal, sedangkan kardus kedua diperlakukan dengan gas etilen yang diberikan pada hari ke-2 perkecambahan. Gas etilen yang digunakan adalah kalsium karbida (karbid) sebanyak 1 gr yang kemudian dicampur dengan air sebanyak 100 $\mathrm{ml}$, pencampuran karbid dengan air ini akan menghasilkan $349 \mathrm{ml}$ asetilen (Purnawan 2010).

\section{HASIL DAN PEMBAHASAN}

Sebelum penelitian dilaksanakan, dilakukan penelitian Sebelum penelitian dilaksanakan, telah dilakukan penelitian pendahuluan yaitu mengecambahkan benih kedelai tanpa sumber etilen eksogen dan mengecambahkan benih kedelai bersama-sama dengan buah pisang yang matang sampai pada tahap kecambah dan buah pisang ini diharapkan sebagai sumber etilen eksogen. Kemudian setelah 5 hari dikecambahkan dilihat bahwa kedelai yang ditumbuhkan bersama-sama dengan buah pisang sebagian besar tumbuh normal untuk semua varietas sehingga tidak terlihat variasi triple response pada ketiga varietas tanaman karena gas etilen yang dihasilkan oleh buah pisang mungkin kurang cukup untuk memicu triple response. Oleh karena itu, digunakan kalsium karbida atau karbid yang menghasilkan gas etilen dengan konsentrasi yang lebih tinggi. Parameter-parameter yang diamati dalam penelitian ini mencakup panjang hipokotil kedelai, diameter hipokotil dan derajat bengkokan kedelai.

Pada penelitian ini digunakan 3 varietas kedelai yaitu Edamamik, Anjasmoro dan Wilis yang ditumbuhkan sampai pada fase kecambah. Bagian-bagian kecambah ketiga varietas kedelai tersebut terdiri dari epikotil, hipokotil dan akar. Pada Gambar A dapat dilihat dari rata-rata panjang varietas Wilis adalah 8,378, Edamamik 8,002 dan Anjasmoro dengan panjang batang terendah yaitu 3,752 , sehingga terlihat perbedaanya dari kedelai tanpa karbid sampai kedelai yang diberi karbid. Begitu pula dari hasil analisis varian (Anava) bahwa faktor perlakuan yaitu kedelai yang tanpa karbid dengan kedelai yang diberi karbid menyebabkan 
perbedaan yang nyata pada panjang kedelai, dimana $F$ hitung dari faktor perlakuan lebih besar dari $F$ tabel sehingga berbeda nyata dan untuk perbedaan yang nyata ini dilanjutkan dengan uji BNT 5\%.

Pada tanaman yang memperlihatkan triple response, pertumbuhan panjang kecambahnya terhambat dan juga terjadi penebalan pada batang. Penebalan ini terjadi karena pemelaran sel ke arah samping sehingga batang cenderung pendek dan tebal (Salisbury dan Ross 1995). Pemelaran sel ke arah samping ini diakibatkan oleh tekanan turgor pada dinding sel yang mengakibatkan sel dalam keadaan turgid (mengembang) (Salisbury dan Ross 1992).

Hasil pengukuran diameter hipokotil kedelai pada ketiga varietas tidak jauh berbeda nilainya. Berdasarkan Gambar 1B maupun hasil Anava tidak ada perbedaan diameter hipokotil kedelai antara yang diberi karbid dan tanpa karbid. Hal ini disebabkan karena tekanan turgor pada sel epidermis menurun dimana keluarnya sebagian air dari sel yang menyebabkan adanya jarak antara dinding sel dan membran sehingga sebagian besar bentuk sel epidermis kedelai adalah memanjang vertikal (Salisbury dan Ross 1992). Karena tidak ada perbedaan yang nyata maka tidak dilakukan uji lanjut BNT.

Epikotil merupakan bagian dari batang kecambah yang membengkok karena etilen. Menurut seorang ahli fisiologi Rusia yaitu Dimitry N. Neljubow 1876-1926 bahwa bengkokan ini memungkinkan batang bertumbuh secara horizontal atau mendatar sehingga pertumbuhan tanaman kedelai menjadi tidak normal (Salisbury dan Ross 1995). Semakin kecil nilai derajat bengkokan kedelai menunjukkan kedelai tahan terhadap etilen dan tidak memunculkan kebiasaan atau membuat bengkokan (hook) yang menyebabkan kedelai tumbuh mendatar.
Pada Gambar 1C terlihat bahwa perlakuan karbid menyebabkan perbedaan derajat bengkokan pada ketiga varietas yaitu Edamamik dengan nilai derajat tertinggi 142,168 diikuti oleh Anjasmoro 123,304 dan Wilis 77,27. Begitu pula dengan kedelai yang ditumbuhkan secara normal rata-rata derajat bengkokan pada Edamamik 56,412, Anjasmoro 45,332 serta Wilis 8,322. Berdasarkan parameter ini varietas yang baik adalah varietas Wilis karena pada pemberian karbid nilai derajat bengkokan pada Wilis terendah. Berdasarkan hal ini dapat diasumsikan sebagian besar kedelainya tumbuh lurus dan epikotilnya pun tidak terlalu membengkok.

Hasil Anava memperlihatkan bahwa faktor varietas dan perlakuan karbid pada bengkokan kedelai adalah sangat berbeda nyata. Terlihat di Gambar 1C derajat bengkokan pada kedelai tanpa karbid dengan yang diberi karbid berbeda dan ada perbedaan pula antara ketiga varietas. Nilai derajat bengkokan pada varietas Wilis adalah $\leq 180^{\circ}$ sedangkan Edamamik dan Anjasmoro yaitu $\geq$ $180^{\circ}$, maka varietas Edamamik dan Anjasmoro adalah yang epikotilnya sangat membengkok.

Terbentuknya bengkokan (hook) pada epikotil kecambah kedelai adalah karena hasil pembelahan dan pemanjangan sel diferensial. Sel-sel bagian dalam bengkokan (hook) memanjang lebih lambat dibandingkan dengan sisi luar dan proses ini dikendalikan oleh etilen serta auksin (Raz dan Koornneef 2001, Raz dan Ecker 1999, Silk dan Ericson 1978, Lehman et al. 1996 dalam Vriezen et al. 2004). Pada tabel Anava F hitung dari faktor varietas dan faktor perlakuan lebih besar dibandingkan dengan $F$ tabel maka dilanjutkan dengan uji BNT 5\%. 

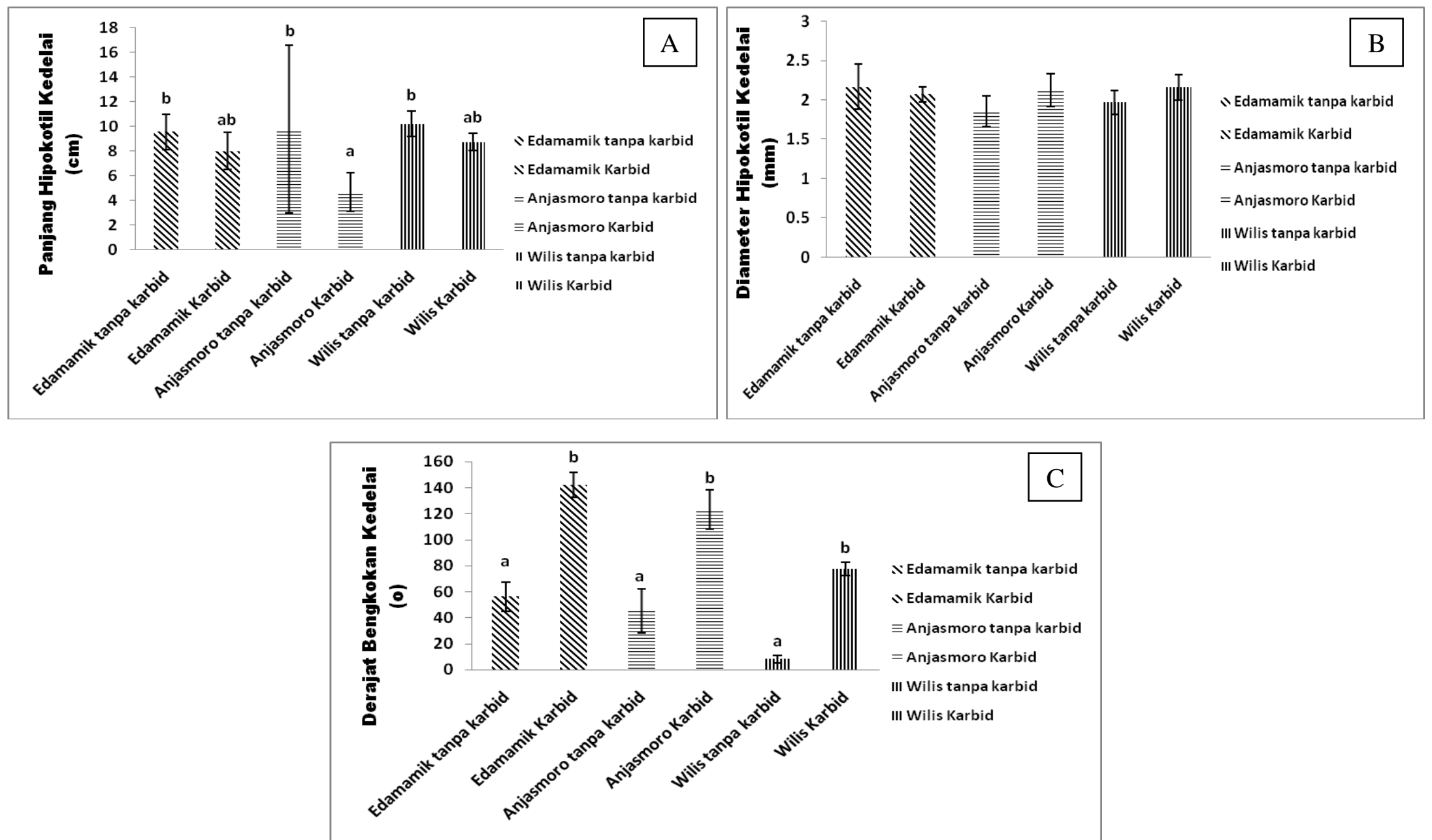

Gambar 1. A. Panjang Hipokotil, B. Diamater Hipokotil dan C. Derajat bengkokan (hook) kedelai. 
Jaringan sel yang diamati pada Jaringan sel yang diamati pada penelitian ini adalah irisan penampang melintang dari sel epidermis hipokotil kedelai. Jaringan epidermis adalah lapisan-lapisan sel yang berada paling luar pada bagian-bagian tumbuhan seperti akar, batang, daun, bunga, buah dan biji. Banyak kajian telah membuktikan bahwa epidermis terdapat pada tumbuhan muda (kecambah), tumbuhan lunak (bayam), tumbuhan kayu (perdu dan pohonpohonan), yaitu diujung ranting dan permukaan daun yang berfungsi melindungi jaringan di bagian dalamnya (Sutrian 2011).

Pada kecambah kedelai yang memperlihatkan triple response yang direfleksikan dengan pertumbuhan batang terhambat dan batang cenderung tebal karena pemelaran sel ke arah samping lebih terpacu. Perubahan bentuk sel disebabkan oleh orientasi mikrofibil selulosa yang diendapkan ke dinding sel, lebih ke arah memanjang sehingga menghambat pemelaran yang sejajar dengan mikrofibil dan hanya memungkinkan pemelaran terjadi dalam arah tegak lurus terhadap mikrofibil (Salisbury dan Ross 1995).

Pada hasil pengamatan irisan sel epidermis dari hipokotil kedelai tidak terlihat adanya perubahan bentuk sel yang besar pada ketiga varietas. Hal ini mungkin disebabkan karena konsentrasi etilen yang dihasilkan oleh karbid belum berpengaruh terhadap bentuk sel dari ketiga varietas kecambah kedelai. Oleh sebab itu perlu dilakukan evaluasi lebih lanjut untuk melihat pengaruh yang lebih besar dari peningkatan konsentrasi etilen terhadap bentuk sel epidermisnya. Sebagai contoh Steward, Liebarman dan Kunishi (1974) melaporkan bahwa pada kecambah kacang kapri bahwa terjadi pemelaran ke samping saat tanaman ditumbuhkan selama 4 hari dalam keadaan gelap dimana bentuk sel berubah ketika diberi perlakuan etilen dengan konsentrasi $0,5 \mu / L$.

\section{KESIMPULAN}

Hasil dari penelitian, diperoleh kesimpulan bahwa di antara ketiga varietas kedelai yang diuji, varietas Wilis yang paling tahan terhadap peningkatan etilen. Kecambah varietas Wilis memperlihatkan tingkatan triple response yang paling rendah yang direfleksikan dengan tinggi kecambah paling besar dan derajat bengkokan (hook) paling kecil.

\section{DAFTAR PUSTAKA}

Arsyad DM (1995) Kedelai sumber pertumbuhan dan produksi dan teknik budidaya. Badan Litbang Pertanian. Puslitbangtan. Bogor

Badan Perbenihan Tanaman Hutan Bali Nusra (2009) Validasi metode uji daya berkecambah benih trembesi (Samanea saman) menggunakan instruksi kerja 08 Laboratorium BPTH Bali \& Nusa

Tenggara.http://bpthbalinusra .net/index.php?option=com_c ontent\&view=article\&id=329: validasi-metode-uji-dayaberkecambah-benihtrembesi-samanea-samanmenggunakan-intruksi-kerja08-laboratorium-bpth-bali-anusa-tenggara\&catid $=1$ : latest-news. Diakses pada tanggal 17 juni 2014

Badan Tenaga Nuklir Nasional (2008) Kedelai varietas unggul baru hasil pemuliaan mutasi radiasi. ISSN-0215-0611

Campbell NA, JB Reece dan LG Mitchell (2002) Biologi Edisi Kelima - Jilid 1. Penerbit Erlangga. Jakarta

Campbell NA JB, Reece Urry LA, Cain ML, Wasserman SA, Minorsky PV, Jackson RB (2012) Biologi Jilid 2- Edisi 


Kedelapan.
Erlangga. Jakarta
Guzman Penerbit
Exploiting the triple response
of Arabidopsis ethylene
related mutants. American
Society of Plant Physiologist.
The Plant Cell. Vol.2 : 513-
514

Hidayat OO (1993) Morfologi tanaman kedelai. Dalam: Buku Kedelai Cetakan Ke-2. Badan Litbang Pertanian. Puslitbangtan. Bogor

Kartasapoerta AG (1992) Teknologi benih: Pengolahan benih dan tuntunan praktikum. Rineka Cipta. Jakarta

Negm BF, Smith OE (1978) Effect of ethylene and carbon dioxide on the germination of osmotically inhibited lettuce seed. Plant Physiol. 62: 473474.

Nio SA, Tondais SM, Butarbutar R. (2010) Evaluasi indikator toleransi cekaman kekeringan pada fase perkecambahan padi (Oryza sativa L.). Jurnal Biologi. ISSN: 1410 5292. XIV (1): 50-51

Purnawan H (2010) Pengertian karbit. Universitas Gadjah Mada. http://haris-

purnawan.web.ugm.ac.id/?pil ih=news\&mod=yes\&aksi=liha t\&id=22. Diakses pada tanggal 2 agustus 2014.

Permanasari I, Katsono D (2012) Pertumbuhan tumpangsari jagung dan kedelai pada perbedaan waktu tanam dan pemangkasan jagung. Jurnal Agroteknologi. 3 (1): 13

Roman GB, Lubarsky J, Kieber J, Rothenberg M, Ecker JR (1995) Genetic analysis of ethylene signal transduction in Arabidopsis thaliana: Five vove; mutant loci integrated into a stress response pathway. The Genetics Society of America: 13941395

Salisbury FB, Ross CW (1995) Fisiologi tumbuhan Jilid 3 Edisi ke-4. ITB. Bandung.

Sumiati N, Sumiati E (2001) Pengaruh vernalisasi, giberelin dan auksin terhadap pembungaan dan hasil biji bawang merah. Jurnal Holtikultura 11 (1):1-8

Susanto GWA, Sundari T (2011) Perubahan karakter agronomi plasma nutfah kedelai di lingkungan ternaungi. Jurnal Agron. Indonesia. 39 (1): 1-2

Turmudi E (2002) Kajian pertumbuhan dan hasil tanaman dalam sistem tumpangsari jagung dengan empat kultivar kedelai pada berbagai waktu tanam. Jurnal IImu-IImu Pertanian Indonesia. ISSN 14111-0067. 4 (2): 89-90

Vriezen HW, Achard P, Harberd PN, Dominique Van Der S (2004) Ethylene-mediated

enhacement of apical hook formation in etiolated Arabidopsis thaliana seedlings is gibberellin dependent. The Plant Journal. 37: 505-516

Waisimon ED (2012) Uji daya hasil beberapa varietas kedelai (Glycine max L. Merril.) berdaya hasil tinggi pada lahan sawah di SP-1 Prafi Manokwari Universitas Negeri Papua 